\title{
Anti-Corruption, Government Subsidies and Corporate Innovation Investment-Based on the Perspective of Rent-Seeking Theory
}

\author{
Yingying Liang, Qi Wang \\ Management School, Jinan University, Guangzhou, China \\ Email: 1298082192@qq.com
}

How to cite this paper: Liang, Y. Y., \& Wang, Q. (2017). Anti-Corruption, Government Subsidies and Corporate Innovation Investment-Based on the Perspective of Rent-Seeking Theory. Chinese Studies, 6, 44-54.

https://doi.org/10.4236/chnstd.2017.61006

Received: January 17, 2017

Accepted: February 21, 2017

Published: February 24, 2017

Copyright $\odot 2017$ by authors and Scientific Research Publishing Inc. This work is licensed under the Creative Commons Attribution International License (CC BY 4.0).

http://creativecommons.org/licenses/by/4.0/

\begin{abstract}
Based on the data of A-share listed companies from 2009 to 2014, this paper discusses the effect of government subsidies on corporation innovation investment under different ownerships by comparing the two groups of stateowned enterprises and non-state-owned enterprises. And we join two factors of the anti-corruption and the process of marketization to further analyze the effect of government subsidies on the adjustment of corporate innovation investment under the environment of the anti-corruption.
\end{abstract}

\section{Keywords \\ Anti-Corruption, Rent-Seeking, Government Subsidies, \\ Corporate Innovation Investment}

\section{Introduction}

Innovation is the driving force of a country's development. And enterprises are the main body of economic activities. To promote enterprise innovation investment is of great significance to promoting China's economic development.

As a national financial tool to adjust the economy, government subsidies act as a guiding role for enterprise innovation investment. As China is in the special period of economic transformation, the phenomenon of rent-seeking is widespread in China's economic development. Due to our special institutional arrangements, there are significant differences in resource acquisition and management practices between different ownership firms (Liang et al., 2012). So the effect of government subsidies on enterprise innovation investment is not the same for different ownership firms.

Since the 18th CPC National Congress, China has intensified its efforts to fight corruption. A large number of government officials and state-owned en- 
terprise executives were investigated for corruption. This provides an opportunity for us to study the relationship between government subsidies and business innovation investment in the context of anti-corruption. Anti-corruption increases the cost of rent-seeking and thus reduces the rent-seeking behavior, which will certainly affect the relationship between government subsidies and corporation innovation investment. So, in the context of economic restructuring, what kind of enterprises is more inclined to use government subsidies for innovation? How does anti-corruption affect the relationships?

This paper uses empirical analysis to analyze the impact of government subsidies on corporation innovation investment on the listed companies from 2009 to 2014.

The contribution of this paper is mainly embodied in two aspects: first, from the perspective of rent-seeking, we analyze the efficiency of government subsidies for enterprise innovation investment and thus expand the theory of rentseeking theory. Second, this paper discusses the effect of anti-corruption on the efficiency of enterprise subsidy. We provide theoretical analysis and explanation for the implementation effect of anti-corruption in China. It has strong practical significance.

The remainder of the paper is structured as follows. Section 1 is the introduction. Section 2 reviews the related literature. Section 3 is theoretical analysis and research hypothesis. Section 4 describes the data and the measurement of key variables. Section 5 presents the main empirical analysis. Section 6 concludes the study.

\section{Review of Literature}

Due to the ease of disclosure and non-complete exclusivity of knowledge in the process of innovation activities, the benefits of corporation innovation investment will be greatly reduced (Xie Weimin \& Tang Qingquan, 2009). Some problems in the innovation process cannot rely on market to deal with. It requires government intervention (Chen et al., 2012). For local governments, decentralization reforms have given local governments sufficient power to intervene in the local economy. The development of local economy is related to the performance and promotion of local officials. So the local government's attitude towards local enterprises become more active (Huang Jie \& Huang Zongjun, 2007). With the change the mode of economic growth, innovation is the main driving force. Local governments began to give subsidies to support the enterprise's innovative behavior.

The government determines the distribution of government subsidies according to the information provided by the enterprises. There is asymmetry of information between government and enterprises. Chen Lin \& Zhu Weiping (2008) argues combined effects of tax and subsidy on innovation investment. An Tongliang, Zhou Shaodong, \& Pi Jiancai (2009) argues that the asymmetry of information between government and enterprises allows companies to make the reverse selection in the process of seeking government subsidies. Enterprises will 
release false signals and it will affect the efficiency of government subsidies. Based on the theory of resource acquisition and signal transmission, Yang Yang \& Wei Jiang (2015) points out that the government subsidy of private enterprises is more important than the state-owned enterprises from the aspects of resource endowment and institutional logic.

\section{Theoretical Analysis and Hypothesis}

1) the effect of government subsidy on enterprise innovation investment under different ownerships

Compared with non-state-owned enterprises, state-owned enterprises have obvious advantages in the resource endowment because state-owned enterprises and local governments have a natural link, which reduces the cost of rent-seeking. For non-state-owned enterprises, it faces the constraints of lacking resources and capital. At this point, non-state-owned enterprises need to make rent- seeking to promote enterprises to innovate. In addition, compared to state-owned enterprises, non-state-owned enterprises have advantages in the organization and management capacity, which can make non-state-owned enterprises use the existing innovation resources more effectively to make innovation output. Based on this consideration, hypothesis 1 is proposed:

H1: Government subsidies have a significant effect on innovation investment for non-state-owned enterprises. But it is not significant for state-owned enterprises.

2) The effect of government subsidy on the innovation performance of enterprises under different political environment

The effect of government subsidies on innovation investment will be affected by the political environment. Specifically, the different political environment will lead to different cost of rent-reeking and thus affect the effectiveness of government subsidies on enterprise innovation investment. In our country, political transparency and market mechanism are still in the process of continuous development and improvement, the power of government lack of effective supervision. In the case of weak anti-corruption efforts, there is no clear legal and institutional constraints on corruption and rent-seeking activities, which leads to a decline in rent-seeking costs. At this point, companies are more inclined to use rent-seeking to obtain other resources and give up the high-risk behavior of enterprise innovation investment to seek development. Obviously, the strengthening of anti-corruption efforts may reduce the rent-seeking behavior of enterprises.

The survival of enterprises is also affected by the local marketization process. In China, the degree of marketization in various regions is very uneven. The market intervention of different regional governments is not the same. For areas with high marketability, the market transparency is higher and the government intervention is less. The anti-corruption is more effective for the government subsidy efficiency. And a high degree of marketization means that the market is also more sensitive to the environment. Anti-corruption to some extent blocked the possibility of rent-seeking. Therefore, hypothesis 2 is put forward: 
$\mathrm{H} 2$ : Under the background of anti-corruption, for the non-state-owned enterprises in the era of high level of marketization process, government subsidies have a more significant effect on innovation investment. But it is not significant for state-owned enterprises.

\section{Data and Research Methods}

\subsection{Sample and Data Sources}

This paper collects the data of A-share listed companies from 2009 to 2014 . We retrieve the data of government subsidies and R\&D investment from the annual report of listed companies. The data of the other research variables, such as the scale of the companies and so on, are from China Stock Market Research Database (CSMAR). In addition, in order to eliminate the effect of extreme values, the important variables in the model are subjected to Winsorize processing at a level of $1 \%$. The sample selection process is as follows: 1) excluding listing Corporation belonging to the financial industry samples; 2) excluding ST listing Corporation. After the screening, we finally get 11,809 samples.

\subsection{Variable Definition}

Based on the previous studies, the scale of companies, profit level and industry will affect the relation between the innovation and government subsidies to a certain extent. Gu Yuanyuan (2011) pointed out that the scale of the enterprise, the ratio of assets to liabilities, and ownership characteristics will affect the effect of government subsidies on R\&D investment. Du Xingqiang \& Zeng Quan (2012) pointed out that the government will consider the profitability of the enterprise when the government decides to provide subsidies to the enterprise. $\mathrm{Hu}$ Rongcai \& Zeng Wangquan (2014) shows that the shareholding proportion of the first major shareholders of listed companies is higher, the corresponding management rent-seeking space is smaller. For such enterprises, government subsidies can make more significant effect to encourage the enterprises to increase the R\&D investment. In this paper, the above variables are controlled in order to better reflect the effect of government subsidies on R\&D investment.

In this paper, $R \& D$ investment is the dependent variable. The government subsidies are independent variables. And we add the assets (the natural logarithm of total assets), the asset-liability ratio, the rate of return on net assets, the shareholding proportion of the first shareholder, industry, year and other control variables to construct the model.

The R\&D investment (ORIRD1): Corporation R\&D investment divided by total assets.

The proportion of government subsidies (SUB1): For different companies, the same amount of government subsidies will have different effects. Therefore, this paper uses the ratio of government subsidies to total assets to eliminate the impact of the size of the company. In the study, we also use the ratio of government subsidies to income to measure SUB 1. 
Enterprise property rights ( $\mathrm{SOE}$ ): If the enterprise is state-owned enterprise, the SOE is 1 , otherwise 0 .

The strength of anti-corruption (TIME): According to the research of Dang Li, Yang Ruilong, \& Yang Jidong (2015), TIME is defined as dummy variables. If the time is after 2013 (including 2013), the virtual variables of anti-corruption is 1 , which suggests that the anti-corruption degree is strong; Otherwise, the virtual variables of anti-corruption is 0 . We take the 2013 as a node of anti-corruption, mainly because the new Chinese government took office in late 2012 to early 2013 and thus the high strength of anti-corruption actually began in 2013. Also, the enterprise R\&D investment decision is generally at the beginning of 2012 . Therefore, innovation decision is not affected by the anti-corruption of 2012 . Taking 2013 as a node, we are better able to capture the impact of anti-corruption on innovation.

Market process index (HHI): We use the market process index (Fang Gang, 2009).

Fixed assets ratio (TANGIBILITY): the ratio of net fixed assets to total assets.

Retained earning ratio (RE): the ratio of retained earnings to total assets.

The total number of patents (SUM): The number of new inventions.

The utility model (INVENTINO): The number of the utility model patent.

\subsection{Descriptive statistics}

Table 1 is the statistical description of main variables. As shown in Table 1, the mean value of ORIRD1 is 0.000552 . Its standard deviation is 0.00241 . The mean value of SUB1 is 0.00574 . Its standard deviation is 0.00868 . So there is a big difference for innovation investment and government subsidies between different companies.

As shown in Table 2, the company's R\&D investment keeps the trend of increasing year by year. But in $2011 \mathrm{R} \& \mathrm{D}$ investment is the largest. The average

Table 1. Statistical description of main variables.

\begin{tabular}{cccccc}
\hline Variable & Obs & Mean & Std.Dev. & Min & Max \\
\hline ORIRD1 & 11,809 & 0.000552 & 0.00241 & 0 & 0.0174 \\
SUB1 & 11,809 & 0.00574 & 0.00868 & 0 & 0.0558 \\
LNASSET & 11,809 & 21.89 & 1.298 & 18.76 & 25.73 \\
TOP1 & 11,809 & 36.01 & 15.42 & 8.930 & 75.78 \\
LEV & 11,809 & 0.468 & 0.234 & 0.0412 & 1.373 \\
ROA & 11,809 & 0.0374 & 0.0590 & -0.250 & 0.226 \\
TOBINQ & 11,809 & 2.023 & 1.833 & 0.195 & 11.25 \\
TANGIBILITY & 11,809 & 0.239 & 0.174 & 0.00186 & 0.736 \\
RE & 11,809 & 0.0925 & 0.331 & -2.249 & 0.522 \\
SUM & 11,809 & 41.10 & 111.5 & 0 & 805 \\
INVENTION & 11,809 & 7.377 & 19.99 & 0 & 134 \\
HHI & 11,809 & 9.056 & 2.074 & 0.380 & 11.80 \\
\hline
\end{tabular}


Table 2. Statistical description of R\&D input by year.

\begin{tabular}{cccccccc}
\hline \multicolumn{7}{c}{ ORIRD } & \\
\hline Year & $\mathrm{N}$ & Mean & Sd & Min & p25 & p75 & Max \\
\hline 2009 & 1517 & $2.660 \mathrm{e}+06$ & $3.460 \mathrm{e}+07$ & 0 & 0 & 0 & $1.230 \mathrm{e}+09$ \\
2010 & 1654 & $3.513 \mathrm{e}+06$ & $5.530 \mathrm{e}+07$ & 0 & 0 & 0 & $1.520 \mathrm{e}+09$ \\
2011 & 1996 & $1.110 \mathrm{e}+07$ & $3.010 \mathrm{e}+08$ & 0 & 0 & 0 & $1.320 \mathrm{e}+10$ \\
2012 & 2251 & $4.718 \mathrm{e}+06$ & $5.770 \mathrm{e}+07$ & 0 & 0 & 0 & $2.160 \mathrm{e}+09$ \\
2013 & 2228 & $5.476 \mathrm{e}+06$ & $7.120 \mathrm{e}+07$ & 0 & 0 & 0 & $2.930 \mathrm{e}+09$ \\
2014 & 2163 & $8.627 \mathrm{e}+06$ & $1.080 \mathrm{e}+08$ & 0 & 0 & 0 & $3.180 \mathrm{e}+09$ \\
Total & 11,809 & $6.218 \mathrm{e}+06$ & $1.400 \mathrm{e}+08$ & 0 & 0 & 0 & $1.320 \mathrm{e}+10$ \\
\hline
\end{tabular}

Table 3. Descriptive statistics of government subsidies.

\begin{tabular}{cccccccc}
\hline \multicolumn{7}{c}{ Subsidies } \\
\hline Year & $\mathrm{N}$ & Mean & Sd & Min & $\mathrm{p} 25$ & $\mathrm{p} 75$ & Max \\
\hline 2009 & 1517 & $2.560 \mathrm{e}+07$ & $1.000 \mathrm{e}+08$ & 0 & 1000000 & $1.630 \mathrm{e}+07$ & $1.870 \mathrm{e}+09$ \\
2010 & 1654 & $3.140 \mathrm{e}+07$ & $1.240 \mathrm{e}+08$ & 0 & $1.381 \mathrm{e}+06$ & $1.980 \mathrm{e}+07$ & $2.500 \mathrm{e}+09$ \\
2011 & 1996 & $3.830 \mathrm{e}+07$ & $1.970 \mathrm{e}+08$ & 0 & $2.049 \mathrm{e}+06$ & $2.170 \mathrm{e}+07$ & $6.730 \mathrm{e}+09$ \\
2012 & 2251 & $4.600 \mathrm{e}+07$ & $2.580 \mathrm{e}+08$ & 0 & $2.550 \mathrm{e}+06$ & $2.510 \mathrm{e}+07$ & $9.410 \mathrm{e}+09$ \\
2013 & 2228 & $4.580 \mathrm{e}+07$ & $2.560 \mathrm{e}+08$ & 0 & $3.131 \mathrm{e}+06$ & $2.900 \mathrm{e}+07$ & $1.030 \mathrm{e}+10$ \\
2014 & 2163 & $5.460 \mathrm{e}+07$ & $2.910 \mathrm{e}+08$ & 0 & $3.538 \mathrm{e}+06$ & $3.070 \mathrm{e}+07$ & $1.090 \mathrm{e}+10$ \\
Total & 11,809 & $4.160 \mathrm{e}+07$ & $2.250 \mathrm{e}+08$ & 0 & $2.282 \mathrm{e}+06$ & $2.400 \mathrm{e}+07$ & $1.090 \mathrm{e}+10$ \\
\hline
\end{tabular}

R\&D investment accounted for $0.0552 \%$ of the total assets. But the distribution is uneven and there is huge variation within different companies. The standard deviation is up to $0.241 \%$

As shown in Table 3, China's government subsidies are increasing year by year. It accounted for $0.574 \%$ of the total assets. The standard deviation is $0.868 \%$. The maximum of subsidy is up to $5.58 \%$.

As shown in Table 4, compared to state-owned enterprises, whether it is government subsidies or R\&D investment, non-state-owned enterprises invest less.

\section{Empirical Results and Analysis}

\subsection{Research on the Relationship between Government Subsidies and R \& D Investment: Based on Different Property Rights}

First of all, to verify the hypothesis 1, in order to explore the effect of government subsidies on the enterprise $\mathrm{R} \& \mathrm{D}$ investment under different property rights, the model 1 was designed.

$$
\text { ORIRD1 }=f\left(S U B_{t-1}, L N A S S E T, T O P 1, L E V, R O A, O R I R D 1_{t-1}, \text { control }\right)
$$

Because the enterprise $R \& D$ investment will have a lag response to government subsidies, the explanatory variables of government subsidies is lagged. 
Table 4. Description statistics in groups.

\begin{tabular}{|c|c|c|c|c|c|c|}
\hline \multicolumn{7}{|c|}{ ORIRD } \\
\hline Ownership & $\mathrm{N}$ & Mean & sd & Min & p50 & Max \\
\hline $\begin{array}{l}\text { Non-state-owned } \\
\text { enterprise }\end{array}$ & 6007 & $4.784 \mathrm{e}+06$ & $7.720 \mathrm{e}+07$ & 0 & 0 & $3.180 \mathrm{e}+09$ \\
\hline $\begin{array}{l}\text { State-owned } \\
\text { enterprise }\end{array}$ & 5802 & $7.704 \mathrm{e}+06$ & $1.840 \mathrm{e}+08$ & 0 & 0 & $1.320 \mathrm{e}+10$ \\
\hline Total & 11809 & $6.218 \mathrm{e}+06$ & $1.400 \mathrm{e}+08$ & 0 & 0 & $1.320 \mathrm{e}+10$ \\
\hline \multicolumn{7}{|c|}{ Subsidies } \\
\hline Ownership & $\mathrm{N}$ & Mean & $\mathrm{Sd}$ & Min & p50 & Max \\
\hline $\begin{array}{l}\text { Non-state-owned } \\
\text { enterprise }\end{array}$ & 6007 & $1.880 \mathrm{e}+07$ & $5.640 \mathrm{e}+07$ & 0 & $6.520 \mathrm{e}+06$ & $2.500 \mathrm{e}+09$ \\
\hline $\begin{array}{l}\text { State-owned } \\
\text { enterprise }\end{array}$ & 5802 & $6.520 \mathrm{e}+07$ & $3.140 \mathrm{e}+08$ & 0 & $1.100 \mathrm{e}+07$ & $1.090 \mathrm{e}+10$ \\
\hline Total & 11809 & $4.160 \mathrm{e}+07$ & $2.250 \mathrm{e}+08$ & 0 & $8.105 e+06$ & $1.090 \mathrm{e}+10$ \\
\hline
\end{tabular}

Table 5. Regression under different property rights.

\begin{tabular}{cccc}
\hline & $(1)$ The full sample & $\begin{array}{c}(2) \text { State-owned } \\
\text { enterprise }\end{array}$ & $\begin{array}{c}\text { (3) Non-state-owned } \\
\text { enterprise }\end{array}$ \\
\hline VARIABLES & ORIRD1 & ORIRD1 & ORIRD1 \\
\hline SUB1 $1_{\mathrm{t}-1}$ & $0.008^{* * *}(2.881)$ & $0.002(1.059)$ & $0.013^{* *}(2.551)$ \\
LNASSET & $0.000^{* * *}(3.073)$ & $0.000(1.274)$ & $0.000^{* *}(2.438)$ \\
TOP1 & $-0.000^{* *}(-2.488)$ & $-0.000^{* *}(-2.302)$ & $-0.000(-1.139)$ \\
LEV & $-0.000(-0.167)$ & $0.000(0.261)$ & $-0.000(-0.703)$ \\
ROA & $-0.000(-1.031)$ & $0.000(0.507)$ & $-0.001(-1.467)$ \\
TOBINQ & $0.000^{* * *}(4.215)$ & $0.000^{*}(1.944)$ & $0.000^{* * *}(3.796)$ \\
TANGIBILITY & $-0.000^{* * *}(-2.783)$ & $-0.000^{* * *}(-2.815)$ & $-0.000(-0.927)$ \\
RE & $0.000^{* * *}(3.613)$ & $0.000(1.307)$ & $0.000^{* * *}(2.672)$ \\
ORIRD1 & $0.557^{* * *}(16.222)$ & $0.530^{* * *}(9.130)$ & $0.573^{* * *}(14.165)$ \\
Industry & control & control & control \\
Year & control & control & control \\
Constant & $-0.001^{* * *}(-2.849)$ & $-0.001(-0.949)$ & $-0.003^{* *}(-2.428)$ \\
Observations & 11,805 & 5798 & 6007 \\
R-squared & 0.311 & 0.297 & 0.323 \\
\hline Ro & & & \\
\hline
\end{tabular}

Robust t-statistics in parentheses; ${ }^{* * *} p<0.01,{ }^{* *} p<0.05,{ }^{*} p<0.1$.

Model (1) describes the relationship between government subsidies and R\&D investment in all samples. As can be seen from the table, the coefficient of the explanatory variable, $\mathrm{SUB}_{\mathrm{t}-1}$, is 0.008 , that is to say, the increase of government subsidies will affect the increase of R\&D investment. The model (2) and the model (3) describe the influence of state-owned enterprises and non-stateowned enterprises' government subsidies on R\&D investment. In the regression of state-owned enterprises, the coefficient of SUB1 $1_{t-1}$ is positive but not signifi- 
cant, while in the regression of the non-state-owned enterprises, the coefficient of SUB $1_{\mathrm{t}-1}$ is 0.013 , higher than the total coefficient of the full sample, and is significant at the $5 \%$ level. It suggests that in the non-state-owned enterprises, government subsidies improve the enterprise $R \& D$ investment level. The emergence of this phenomenon, from the perspective of rent-seeking, may be due to the different nature of rent-seeking for different enterprises. On one hand, stateowned enterprises have natural "political connections" property and thus the cost of rent is low. On the other hand, the development of state-owned enterprises is mainly affected by government intervention and support. So the rent-seeking motive of state-owned enterprises is not strong. According to the efficiency hypothesis or the theory of signal transmission, state-owned enterprises have no great motivation to improve the efficiency of R\&D subsidies. Compared with the state-owned enterprises, non-state-owned enterprises are more active in the attitude of rent-seeking because they have no natural political ties and the access to political resources is difficult. The hypothesis 1 is verified.

\subsection{The Effect of Government Subsidies on Enterprise Innovation Investment under Different Political Environment}

Based on the hypothesis 1, we adding TIME and HIHI as well as their cross multiply to research the impact of corruption subsidies on enterprise innovation investment under the different process of marketization. To verify the hypothesis 2 , the model 2 was designed.

ORIRD1 $=f\left(T I M E, H H I, S U B 1_{t-1}, T H, T S U B_{t-1}, H S U B_{t-1}, T H S U B_{t-1}, C O N T R A L\right)$

The model (1) and (2) in Table 6 represent the sample of state-owned enterprises and non-state-owned enterprises, respectively. And we add HIHI as well as the cross multiply $\left(\mathrm{HSUB}_{\mathrm{t}-1}\right)$. The results showed that the regression coefficient of $\mathrm{HSUB}_{\mathrm{t}-1}$ were not significant, indicating that the impact of government subsidies on corporate R\&D expenditures may be affected by market factors. We need make further subdivision to come to conclusion. In model (3) and (4), we add the dummy variables of anti-corruption, TIME, and the cross multiply (TSUB $_{t-1}$, HTSUB $\left._{t-1}\right)$. As can be seen from the results, for state-owned enterprises, the coefficient of HTSUB $1_{t-1}$ is not significant, while for the private enterprises, the coefficient of HTSUB $1_{t-1}$ is positive and significant at $5 \%$ level. This shows that the impact of anti-corruption on the efficiency of enterprise innovation investment subsidies has significant impact on private enterprises. Again, the hypothesis is verified. And for the private enterprises, the level of marketization process is higher, the impact of anti-corruption on the efficiency of innovation subsidies is greater. This is because, first of all, the higher the level of the marketization process, indicating that the market is more transparent and effective, the smaller the cost of anti-corruption and the greater the effectiveness of anti-corruption. And thus the impact on the behavior of the enterprise will be stronger. Secondly, a high degree of marketization means that the market is more sensitive to the environment. From the perspective of resource allocation, 
Table 6. Regression under different political environments.

\begin{tabular}{|c|c|c|c|c|}
\hline & $\begin{array}{l}\text { (1) State-owned } \\
\text { enterprise }\end{array}$ & $\begin{array}{c}\text { (2 Non-state-owned } \\
\text { enterprise }\end{array}$ & $\begin{array}{l}\text { (3) State-owned } \\
\text { enterprise }\end{array}$ & $\begin{array}{l}\text { (4) Non-state- } \\
\text { owned enterprise }\end{array}$ \\
\hline VARIABLES & ORIRD1 & ORIRD1 & ORIRD1 & ORIRD1 \\
\hline TIME & & & $0.000^{*}(1.81)$ & $0.001^{\star \star \star}(2.968)$ \\
\hline HHI & $0.000(1.022)$ & $-0.000(-1.423)$ & $0.000(1.380)$ & $-0.000(-0.324)$ \\
\hline $\mathrm{SUB1}_{\mathrm{t}-1,}$ & $-0.004(-0.332)$ & $0.051(1.128)$ & $-0.007(-0.573)$ & $0.080^{\star}(1.667)$ \\
\hline $\mathrm{TH}$ & & & $-0.000(-1.388)$ & $\begin{array}{l}0.000^{\star * *} \\
(-2.896)\end{array}$ \\
\hline TSUB $_{\mathrm{t}-1}$ & & & $0.009(0.376)$ & $\begin{array}{l}-0.072^{\star *} \\
(-2.293)\end{array}$ \\
\hline HSUB $_{t-1}$ & $0.001(0.561)$ & $-0.003(-0.706)$ & $0.001(0.781)$ & $-0.006(-1.275)$ \\
\hline THSUB $_{\mathrm{t}-1}$ & & & $-0.001(-0.462)$ & $0.007^{\star *}(2.009)$ \\
\hline LNAASET & $0.000(0.228)$ & $0.000^{* \star}(2.165)$ & $0.000(0.220)$ & $0.000^{* *}(2.139)$ \\
\hline TOP1 & $-0.000^{\star \star}(-2.295)$ & $-0.000(-1.573)$ & $-0.000^{\star \star}(-2.298)$ & $-0.000(-1.584)$ \\
\hline LEV & $0.000(1.256)$ & $-0.000(-1.310)$ & $0.000(1.288)$ & $-0.000(-1.281)$ \\
\hline ROA & $0.000(0.535)$ & $-0.001^{\star}(-1.888)$ & $0.000(0.530)$ & $-0.001^{*}(-1.886)$ \\
\hline TOBINQ & $0.000^{\star}(1.855)$ & $0.000^{\star * \star}(3.733)$ & $0.000^{\star}(1.873)$ & $0.000^{\star \star \star}(3.755)$ \\
\hline TANGIBILITY & $0.001^{\star * *}(-3.337)$ & $-0.000(-1.383)$ & $0.001^{\star * *}(-3.351)$ & $-0.000(-1.324)$ \\
\hline $\mathrm{RE}$ & $0.000(1.400)$ & $0.001^{\star * \star}(2.983)$ & $0.000(1.426)$ & $0.001^{\star * \star}(3.028)$ \\
\hline \multirow[t]{2}{*}{ INVENTION } & $0.000^{\star *}(2.356)$ & $0.000^{\star \star}(2.554)$ & $0.000^{\star *}(2.367)$ & $0.000^{\star * *}(2.583)$ \\
\hline & $(-0.573)$ & $(0.133)$ & $(-0.573)$ & $(0.113)$ \\
\hline Industry & control & control & control & control \\
\hline Constant & $-0.000(-0.354)$ & $-0.003^{*}(-1.838)$ & $-0.000(-0.450)$ & $-0.004^{\star}(-1.955)$ \\
\hline Observations & 5798 & 6007 & 5798 & 6007 \\
\hline $\mathrm{R}$-squared & 0.048 & 0.069 & 0.048 & 0.070 \\
\hline
\end{tabular}

Robust t-statistics in parentheses; ${ }^{* * *} p<0.01,{ }^{* *} p<0.05,{ }^{*} p<0.1$.

anti-corruption reduce the possibility of rent-seeking to a certain extent. The improvement of the efficiency of resources allocation is more obvious in the area with higher level of marketization. Therefore, for the private enterprises, the higher the level of the marketization process, the greater the impact of anti-corruption on the efficiency of enterprise innovation investment subsidies. The hypothesis 2 is verified.

\section{Conclusion}

Based on the data from 2009 to 2014, this paper makes an empirical study on the effect of government subsidies on enterprise innovation investment under different ownership systems by using the DID double difference method. Research shows that strengthening anti-corruption efforts can increase significantly the enterprise $\mathrm{R} \& \mathrm{D}$ investment. It suggests that if the efforts of anti-corruption are stronger, the enterprise rent-seeking space will become smaller and the process of government subsidies to enterprises will gradually be more transparent and 
standardized. Because the cost of rent-seeking increases, enterprises have to put more energy into the production innovative activities rather than rent-seeking activities. At the same time, this paper also examines the efficiency of China's R\&D subsidies by the level of marketization factors. Empirical tests show that the high level of marketization is conducive to the implementation of anti-corruption measures.

Through the empirical study of this paper, it shows that anti-corruption has an obvious effect on improving the efficiency of innovation subsidies, especially for private enterprises. We need to increase the intensity of anti-corruption, curb the possibility of rent-seeking and supervise strictly government subsidies process. At the same time, it is necessary to improve the judicial system, reduce the government's administrative intervention to the enterprise and improve the autonomy of the enterprise. Only a perfect judicial system and a higher level of marketization can produce a more transparent, more lasting protection to enterprises.

\section{References}

An Tongliang, Zhou Shaodong, \& Pi Jiancai. 安同良, 周绍东, 皮建才. (2009). The Stimulating Effects of R\&D Subsidies on Independent Innovation of Chinese Enterprises R\&D 补贴对中国企业自主创新的激励效应. Journal of Economic Research, No. 10, 132-155.

Chen Lin, \& Zhu Weiping. 陈林, 朱卫平. (2008). Policy Effect of Rebating Export Tax and Subsidizing Innovation in Innovation Incentive 出口退税和创新补贴政策效应研 究. Journal of Economic Research, No. 11, 55-78.

Chen, V. Z., Li, J., Shapiro, D. M., \& Zhang, X. (2012). Ownership Structure and Innovation: An Emerging Market Perspective, Asia Pacific. Journal of Management, 1-24.

Dang Li, Yang Ruilong, \& Yang Jidong. 党力, 杨瑞龙, 杨继东. (2015). Anti-Corruption and Enterprise Innovation: An Explanation Based on Political Relevance 反腐败与企 业创新：基于政治关联的解释. China Industrial Economy, No. 7, 176-185.

Du Xingqiang, \& Zeng Quan. 杜兴强, 曾泉. (2012) Rent-Seeking, R\&D Investment and Corporate Performance-Empirical Evidence Based on Private Listed Companies 寻 租、 $\mathrm{R} \& \mathrm{D}$ 投资与公司业绩一基于民营上市公司的经验证据. Journal of Investment Research, No. 1, 186-199.

Gu Yuanyuan. 顾元媛. (2011) Rent-Seeking Behavior and Loss of R\&D Subsidy Efficiency 寻租行为与 $\mathrm{R} \& \mathrm{D}$ 补贴效率损失. Journal of Economic Science, No. 5, 123-145.

Hu Rongcai, \& Zeng Wangquan. 胡荣才, 曾汪泉. (2014). The Research on Government Subsidies Differential Effects at Provincial and Industrial Level-Based on Listed Companies in Six Provinces of Central China 政府补贴的省际与行业差异效应研究一以 中部六省上市公司为例. Chinese Journal of Management Science, No. 1, 154-171.

Huang Jie, \& Huang Zongjun. 黄洁, 王宗军. (2007). A Study on the Relationship between the NO.1 Large Shareholder's Shares Holdings and Company's Performances 第 一大股东持股比例与公司业绩的关系研究. East China Economic Management, No. 2, 136-153.

Liang, X., Lu, X., \& Wang, L. (2012). Outward Inter-Nationalization of Private Enterprises in China: The Effect of Competitive Advantages and Disadvantages Compared to Home Market Rivals. Journal of World Business, 134-144.

Xie Weimin, \& Tang Qingquan. 解维敏, 唐清泉. (2009). Government R\&D Grants, 
Corporate R\&D Expenditure and Independent Innovation-Empirical Evidence from Chinese Listed Companies 政府 R\&D 资助、企业 R\&D 支出与自主创新一来自中国 上市公司的经验证据. Journal of Financial Research, No. 6, 158-177.

Yang Yang, \& Wei Jiang. 杨洋, 魏江. (2015). Who Is Using Government Subsidies to Innovate? 谁在利用政府补贴进行创新? Journal of Management World, 2015, 169196.

Submit or recommend next manuscript to SCIRP and we will provide best service for you:

Accepting pre-submission inquiries through Email, Facebook, LinkedIn, Twitter, etc. A wide selection of journals (inclusive of 9 subjects, more than 200 journals)

Providing 24-hour high-quality service

User-friendly online submission system

Fair and swift peer-review system

Efficient typesetting and proofreading procedure

Display of the result of downloads and visits, as well as the number of cited articles Maximum dissemination of your research work

Submit your manuscript at: http://papersubmission.scirp.org/

Or contact chnstd@scirp.org 